\title{
FORMS OF ACTIVITIES WITH A DOG AS MODERN TYPES OF PHYSICAL RECREATION
}

\author{
Monika Niewiadomska \\ University of Szczecin, Faculty of Physical Culture and Health Promotion, Poland \\ Address for coprespondence: \\ Monika Niewiadomska \\ Faculty of Physical Education and Health Promotion, University of Szczecin \\ Al. Piastów 40 b, bl. 6, 71-065 Szczecin, Poland \\ E-mail: monikaniewiadomska@wp.pl
}

\begin{abstract}
Ahstract The rapid civilisational development that took place in the second half of the 20th century, and the resulting changes in the conditions and ways of people's lives brought forth a number of social phenomena, both positive and negative. Physical activities, i.e. any forms of physical effort undertaken voluntarily in leisure time for entertainment and health purposes, contribute greatly to overcoming the dangers of modern civilization. Among these, activities with the participation of a dog are becoming increasingly popular. These activities are exercised by people of all ages in the form of dog sports, as well as for recreational and therapeutic purposes.

The aim of the paper is to present various forms of activities with a dog as modern types of physical recreation exercised by people of all ages.

Regular exercise with a dog greatly improves the well-being and provides a feeling of harmony and inner peace. It is becoming yet another modern form of activity.
\end{abstract}

Key Words physical activity, agility, type 1 diabetes, dog sports

\section{Introduction}

Various specialists consider exercise to be one of the pre-requisites of maintaining or improving one's health (Jaskólski, 2002; Skarżyński, 2003).

The effects of physical activity on the human body are not limited to the physical aspects. "There is also an entire range of psychological and, more precisely, psychosocial outcomes" (Sas-Nowosielski, 2003, p. 22). Specialists view physical activity as a form of therapy for specific mental and emotional disorders. Moreover, regular physical exercise contributes to alleviating anxiety and depressive mood, and enables the development of selfesteem (Sas-Nowosielski, 2003). 
Nowadays, work takes up major part of the day, and its conditions, employers' demands and stress levels are increasing. Fast pace of living, higher workload, continuous necessity to make choices, desire of pursuing one's career are a few of the many factors that impact our mental health and cause mental fatigue.

Prolonged nervous stain and excessive amount of overlapping stressors adversely affect human health, and may result in mental fatigue, nervous breakdown, or even depression. The lifestyle of continuous rush makes it necessary to look for forms of recreation that make it possible to relax and relieve some of the increasing nervous tension. With a view to mental health, it is very important to use leisure time skillfully (Cynarski, 2017). The great popularity of the dog as a pet animal has recently resulted in the establishment of a number of new sports with the participation of dogs (Jastrzębska, Gugołek, Strychalski, 2017). This type of physical activity of a person with a dog may be of sport, recreational, or therapeutic nature.

Conducting therapeutic classes with the participation of a dog is a very complex issue. Due to its extensiveness and diversity of forms of dogotherapy, it will be described in a separate article. This work aims to show the types of cynological sports that have been created. Certainly their diversity contributes to the increase in the number of people undertaking such physical activity. At the present moment, it is not possible to estimate the number of people practicing kennel sports. They are taken by people who repeatedly create informal clubs for dog lovers and do not have to be members of canine associations. Hence, the lack of reliable data on the number of people taking forms of activity with the dog.

\section{Common forms of physical activity involving dogs}

From the very beginning, when a man domesticated a dog, the dog was to serve a man. Initially, they were so-called guardians of the herd. Over the years, dogs of dog breeds arose due to their usefulness. Considering the cynological sports, depending on the discipline, dogs are also picked up in terms of races, predispositions (Journal, 2013; Buss, 2001).

Today, in Poland and all over the world, there are many activities involving dogs. The most popular ones include: agility, obedience, flyball, tracking, dogtrekking, sheep herding.

\section{Obedience}

Obedience as a dog sport involves training a dog in a so-called basic obedience. At the right time and upon a cue, the dog should follow the given commands. This discipline originated from the training of police and military dogs, and the German Shepherd was one of the first breeds to receive such a training. Over time, obedience evolved into a dog sport, with its own rules, regulations, and competitions at various levels of difficulty. In Poland, both pure breed and non-breed dogs may participate in obedience competitions and tests. To be admitted to a competition, a dog must have its start sheet and must be of sound health. Obedience competitions of the following classes are held in Poland:

- Class 0 - for beginners,

- Class 1 - for advanced participants,

- Class 2 - for advanced participants,

- Class 3 - for advanced participants; international rules established by $\mathrm{FCl}$ apply.

A competition is supervised by a commissioner, secretary and a competition supervisor (http://www.szkolenie. lodz.zkwp.pl/praca-psa-pasterskiego). 
Obedience as a dog sport is particularly popular among dog lovers and dog owners. It does not involve huge costs, nor requires specialised equipment. It does require, however, regular physical exercise with the dog. This activity involves systematic training, but also daily walking and working with the dog. It has a positive impact on the mental health and allows a person to relax after a hard day's work.

Rally-o is a more popular, recreational form of obedience. This form has its own rules, less stringent than the original discipline.

Nowadays many training methods are used. Each of them is designed to best train your dog. Currently, this discipline as well as other disciplines put a great emphasis on the use of training methods based on the rewarding of a dog. The use of aversive methods and electric collars mostly leads to increased aggression in a dog or socalled learned helplessness. This, of course, disrupts the relationship between the dog and the guide (Salomon, Wynne, 1953; Schilder, Van der Borg, 2004).

\section{Herding}

Herding is another form of activity with a dog. This discipline originates from the use of utility dogs that helped farmers in their work. It involves the cooperation between a man and a dog with mutual understanding and trust. Shepherd dogs of various kinds are used in herding all over the world, but most it involves Border Collie, a breed best suited for this task. This activity has its origins in England. Dog trial is a herding competition held all over the world. It is particularly popular in the British Isles, where it is regarded to be almost a national sport. In Poland, herding is still a developing discipline, but one that keeps attracting more and more fans. This form of physical activity involves great commitment of the guide and immense emotions. This sport requires exceptional consistency and great effort by both a man and a dog (http://www.szkolenie.lodz.zkwp.pl/praca-psa-pasterskiego).

\section{Flyball}

Flyball is a much less popular sport. It involves racing of dog teams against each other. Each dog has to run through four hurdles to a box that, when pressed with a paw (or the entire body for small and lightweight dogs), ejects a ball to be caught by the dog, who then returns to the owner as fast as possible. Flyball is run in teams of four dogs. It was created following and idea of a Californian Herbert Wagner, who invented a tennis ball thrower in the 1970s (https://pl.wikipedia.org/wiki/Flyball).

Regrettably, this sport is a frequent cause of dog injuries, and does not require handlers to make physical effort. It is a very rare form of activity in Poland.

\section{Dogifishee}

Disc dog is a discipline that requires a lot of physical activity, precision and good coordination of movement of the handler. The sport involves a man throwing frisbee to be caught by a dog. The handler demonstrates various techniques of throwing, and the dog catches the disk by various methods. There are two categories of this sport: long distance, which requires a disc to be thrown as far as possible to be caught by the dog before it falls onto the ground, and freestyle involving a combination of various disc throws, often accompanied with gymnastic exercises and catching the disc by the dog by various techniques. Today, national and international disc dog competitions are held. 


\section{Dogtrekking}

Dogtrekking is another sport involving cross country running with dogs. There are various distances to be made as fast as possible, following the respective checkpoints. The most popular distances are 10-15 and 20$25 \mathrm{~km}$. They can be, however, freely set for the purposes of a competition. The first to pass all the checkpoints is the winner. This sport can be exercises by entire families and dogs of all breeds.

\section{Dog agility}

Agility can be exercised as a sport, recreational activity, or a supportive treatment method for children and adults. It involves directing a dog to complete series of obstacles. Agility was developed in the 1970s, and was originally intended to be an interlude during dog shows. The first public demonstration of dog agility was held at the most famous Cruft's Dog Show in 1978. It instantly turned out to be enormously popular. Within a short time the British Kennel Club established dog agility rules. The World Canine Organization (Fédération Cynologique Internationale - FCl) adopted the dog agility rules and since 1991 considers it to be a sport. (www.zkwp-szkolenie. pl/dyscypliny/agility/agility_regulaminy).

Agility was modelled on equestrian competitions. The sizes and types of obstacles were made different over time, which made this sport very spectacular.

Each participant of a competition starts in three events: agility open, jumping open, and the so-called tests (A0, A1, A2, A3). Flawless completion of a class at three different competitions promotes the participant to the next class. The final classification includes the combined results of the agility open and jumping. A disqualification at any of these excludes the participant from the competition. An agility course and a jumping course differ in terms of the use of obstacles. Agility combines nimbleness and speed. If the time result is the same, the couple (dog + handler) who made fewer mistakes in completing the course is the winner. Agility as a dog sport is also practiced at a competitive level as a national cup and championship, as well as world championship. Today, it is also developed as a form of recreation for children, young people and adults.

Agility requires a systematic approach that promotes physical fitness. The intensity of agility trainings depends mostly on two factors: age and physical fitness of a person and the age and psychophysical capabilities of a dog. Some dog breeds are particularly suitable for agility. These breeds should be characterised by exceptional energy and willingness to cooperate with people. They mostly include $\mathrm{FCl}$ group I breeds. Border Collie and Pyrenean Shepherd are particularly suitable. The owners of these breeds dedicate much more time and effort to their daily trainings than the owners of other breeds, which translates into much better results at sports competitions. Breeds with milder temperament also take part in dog agility, and are mostly preferred by older people with diminished physical fitness and constitution. The latter, however, is no obstacle in participating in dog agility trainings and competitions. Today dog agility events are organised at a regional level for those who treat it as a form of recreation, and also on an international level, e.g. as World Championships where the best dog agility contestants of various countries compete against each other. Dog training in the direction of agility changes its thinking and has a positive effect on the way the dog communicates with the guide (Marshall-Pescini, Paddalacqua, Barnard, Valsecchi, PratoPrevide, 2009; Ekman, Davidson, 2004; Cantazaro, 2003).

Agility is not only physical exercise, but also a means of developing an immense bond with the dog, and sharing extraordinary emotions. Taking advantage of this particular aspect of this activity, in Szczecin agility was suggested as a supportive treatment for children with type 1 diabetes as a means of increasing insulin sensitivity. 
Agility events were adapted to the abilities of children with type 1 diabetes (Otto-Buczkowska, Jarosz- Chobot, 2001; Ponikowska, Adamczyk, 2006). The training cycle resulted in lowering the level of HbA1c glycated haemoglobin, and reduced daily doses of insulin. The contact with a dog also positively influenced the psyche of a child, increased his confidence and was a source of many positive emotions (Niewiadomska, Radzijewska, 2008; Niewiadomska, Radzijewska, Horodnica-Józwa, Petriczko, 2010).

Another example of taking advantage of a contact with a dog as a form of therapy is the implementation of a project in 2016 at a Penal Institution in Goleniów aimed at helping prisoners in rehabilitation. The project was founded by a former employee of the Penal Institution, Mr. Tomasz Wojciechowski, and an employee of the Goleniów Society for Animal Care - Mrs. Ewelina Pietrzak-Giec. Dogs from the Goleniów Society for Animal Care were assigned to selected inmates, who were asked to take care of the dogs for 6 weeks. Apart from basic dog care, i.e. feeding, cleaning, and walking, the inmates learned about various forms of activity with a dog and dog sports, including agility. The inmates managed to establish a bond with the dog, expressed empathy towards it, and commitment in the care. After the end of the project, many inmates kept asking about the dogs.

\section{Summary}

Forms of activity with a dog include sport, recreation, or therapy. Regardless of the form of classes, the key element in running a dog is the proper selection of training methods. The best training effects can be obtained by rewarding the dog. The use of aversive methods, punishments does not bring the desired results and may lead to aggression (Blackwell, Twells, Seawright, Casey, 2008).

Regular exercise with a dog greatly improves well-being, provides a feeling of harmony and inner peace, and can constitute a way of coping with stress. Taking advantage of such forms of activity with a dog may be one of today's types of recreations that is a source of both satisfaction and pleasure.

\section{References}

Adamowicz, S. (2017). Pies paserski. Retrieved from: http://www.szkolenie.lodz.zkwp.pl/praca-psa-pasterskiego.

Blackwell, E.J., Twells, C., Seawright, A., Casey, R.A. (2008). The relationship between training methods and the occurrence of behavior problems, as reported by owners, in a population of domestic dogs. Journal of Veterinary Behawior, 3, 207-217.

Buss, D. (2001). Psychologia Ewolucyjna. Gdańsk: GWP.

Cantazaro, D.A. (2003). Motywacje i emocje. Poznań: Zysk i S-ka.

Cynarski, W.J. (2017). Czas wolny, turystyka i rekreacja w perspektywie socjologicznej. Kraków: Universitas.

Dencikowska, A., Drozd, S., Czarny, W. (2008). Aktywność fizyczna jako czynnik wspomagający rozwój i zdrowie. Rzeszów: University of Rzeszów.

Ekman, P., Davidson, R.J. (1998). Natura emocji. Podstawowe zagadnienia. Gdańsk: Wydawnictwo Psychologiczne.

Federation CynologiQue Internationale (FCl) (207). Regulamin agility. Retrieved from: www.zkwp-szkolenie.pl/dyscypliny/agility/ agility_regulaminy.

Jarosz-Chobot, P. (2006). Epidemiologia cukrzycy typu 1. In: E. Otto-Buczkowska (ed.), Cukrzyca typu 1. Wrocław: Cornetis.

Jaskólski, A. (ed.) (2002). Podstawy fizjologii wysiłku fizycznego. Wrocław: Academy of Physical Education.

Kuński, H. (2002). Trening zdrowotny osób dorosłych. Poradnik lekarza i trenera. Warszawa: AG Medsportpress.

Jastrzębska, A., Gugołek, A., Strychalski, J. (2017). Zwierzęta w sporcie, rekreacji i rozrywce, cz. 1. Wiadomości Zootechniczne, 55 (1), 87-93.

Journal (2013). Of the International Society for Preservation of Primitive Aboriginal Dogs, 35. 
Marshall-Pescini, S., Passalacqua, Ch., Barnard, S., Valsecchi, P., Prato-Previde, E. (2009). Agility and search and rescue training differently affects pet dogs' behaviour in socio-cognitive tasks. Behawior Prosesses, 81, 416-422.

Niewiadomska, M., Radziejewska, M. (2008). Uzasadnienie konieczności wykorzystania wysiłku fizycznego w leczeniu dzieci z cukrzycą typu I. Pedagogic, Psychology, Medical-Biological Problems of Psyhical Training and Sports, 5, 161-164.

Niewiadomska, M., Radzijewska, M., Horodnica-Józwa, A., Petriczko, E. (2010). Wykorzystanie agility jako formy rekreacji w leczeniu dzieci z cukrzycą typu 1. Pediatric Endokrynolog Diabetes and Metabolizm, 16 (2), 89-93.

Otto-Buczkowska, E., Jarosz-Chobot, P.( 2001). Wpływ wysiłku fizycznego na homeostazę glukozy u osób z cukrzycą. Med. Metabol., 2, 37-41.

Ponikowska, I., Adamczyk, P. (2006). In: Otto-Buczkowska (ed.), Wysiłek fizyczny - ważny element leczenia cukrzycy typu 1. Cukrzyca typu 1. Wrocław: Cornetis.

Sas-Nowosielski, K. (2003). Wychowanie do aktywności fizycznej. Katowice: Academy of Physical Education.

Schilder, M.B.H., Van der Borg, J.A.M. (2004). Training dogs with help of the shock collar: short and long term behavioural effects. Applied Animal Behaviour Science, 319-334.

Skarżyński, J. (2003). Biegiem po zdrowie. Szczecin: Mega Sport.

Solomon, R.L.,Wynne, L.C. (1953). Traumatic avoidance learning: acquisition in normal dogs. Psychol. Monogr., Gen. Appl., 67 (4), 1-19.

Ziemian, P. (2018). Flyball. Retrieved from: https://pl.wikipedia.org/wiki/Flyball.

Cite this article aS: Niewiadomska, M. (2018). Forms of Activities with a Dog as Modern Types of Physical Recreation. Central European Journal of Sport Sciences and Medicine, 3 (23), 53-58. DOI: 10.18276/cej.2018.3-05. 